\title{
透水性構造物の抵抗係数の評価と波・潜水透水性構造物の 非線形相互作用の数值解析
}

\author{
水 谷 法 美* - 前田健一郎** - Ayman M. Mostafa*** \\ William G. McDougal***
}

\section{1. 緒}

近年, 景観面および海水交換性に優れる幅広潜堤工法 が注目されている。幅広潜堤の耐波安定性に関しては, 堤体自体の安定性の他に被覆捨石が移動しないことが重 要であり,その必要安定重量を力学的に評価することが 防災上重要である. 最近, 被覆捨石の移動機構を考慮し た安定重量算定手法が提案されており（水谷ら，1994）, 捨石の作用波力が予測できればその手法の適用は可能で ある. 一方，捨石の作用波力の予測については Morison 式の有効性が示されている(Rufin ら，1993)が, Morison 式に必要な流速場の予測手法の構築が必要である.

潜堤のような潜水式透水性構造物による波の変形の数 值計算は多く行われているが（例えば，榊山，1992；水 谷ら，1995）, 堤体内部の流体運動の運動方程式に含まれ る抵抗項の係数の評価は十分に論議されているとはいい がたい. したがって, 潜堤による波変形や内部流速場を 精度良く予測するためには, 抵抗係数の評価は必要不可 欠である。

堤体内部の流れが受ける抵抗は, 堤体の構成材の作用 波力の反力として考えることができる.すなわち，構成 材の作用波力から抵抗係数を評価することが可能であ る. 本研究は, 幅広潜堤の被覆材の作用波力の実験結果 より, 潜堤内部流速場に対する抵抗係数を評価し, さら にその結果を強非線形モデルに基づく潜水透水性構造物 による波浪変形計算モデルに導入することにより，より 信頼性の高い潜水透水式構造物による波変形と内部流速 場の解析手法を構築することを目的とする.

\section{2. 数 值 解 析}

本研究では, 水平な海底上に幅広潜堤が設置された場 合を対象とする. 流体領域を潜堤の内外にわけ，外部で は, 完全流体の非回転運動を仮定し速度ポテンシャルと 水位変動を未知変数として境界積分方程式を解く。潜堤 表面での透水性以外は, 大山（1991）の数值波動水槽と

\footnotetext{
${ }^{*}$ 正会員 工 博 名古屋大学助教授 工学研究科土木工学教室

** 正会員 工 修 佐藤工業 (株) 技術本部土木設計部

*** M.Eng. 名古屋大学大学院 工学研究科土木工学専攻

**** Ph.D. オレゴン州立大学教授 工学部土木工学科
}

全く同様の手法を採用している.

一方, 内部領域は回転性を考慮できるよう, 水平 $(x) \cdot$ 鉛直 $(z)$ 方向の流量流速 $u$ と $w$ ，および圧力 $p$ を末知数 として重み付残差法に基づく有限要素法により解析を行 う. 基礎方程式は, 以下に示す連続式 ( 1 ）と $x, y$ 方向 の運動方程式（2），（3）である.

$$
\begin{aligned}
& \frac{\partial u}{\partial x}+\frac{\partial w}{\partial z}=0 \\
& A \frac{\partial u}{\partial t}+B\left(u \frac{\partial u}{\partial x}+w \frac{\partial u}{\partial z}\right)+C \frac{\partial P}{\partial x}+D u \\
& +E u \sqrt{u^{2}+w^{2}}=0 \text {. } \\
& A \frac{\partial w}{\partial t}+B\left(u \frac{\partial w}{\partial x}+w \frac{\partial w}{\partial z}\right)+C \frac{\partial P}{\partial z}+D w \\
& +E w \sqrt{u^{2}+w^{2}}=0
\end{aligned}
$$

ここに，P=p+ $\rho g z$ である. 式（2）と（3）に含まれ る係数 $A \sim E$ は一方向流れに対して以下のように与え られている (McCorquodale・Hannoura, 1978)。

$$
\left.\begin{array}{l}
A=\frac{1}{m g}\left(1+\frac{1-m}{m} C_{A}\right), \quad B=\frac{1}{m^{2} g} \\
C=\frac{1}{\rho g}, \quad D=\frac{4.6 \nu}{g m d^{2}}, \quad E=\frac{0.79}{g m^{0.5} d}
\end{array}\right\}
$$

ここに, $C_{A}$ : 付加質量係数, $m$ : 間隙率, $\rho$ : 水の密度, $\nu:$ 水の動粘性係数, $d:$ 空吵の代表長さ, $g$ :重力加速 度,である。

本研究では，後述するように，これらの係数を幅広潜 堤の被覆材の作用波力から評価した值を使用した。それ 以外は水谷ら（1995）が用いた手法をそのまま使用して 数値解析を行った.

\section{3. 水理実験}

2 次元鋼製水槽（長さ $25 \mathrm{~m}$, 幅 $0.7 \mathrm{~m}$, 高さ $0.9 \mathrm{~m}$ ) 内に法面勾配 $1 / 3.2$, 天端幅 $B=220 \mathrm{~cm}$, 天端水深 $7 \mathrm{~cm}$ の幅広潜堤模型を直径 $D$ が $3.0 \mathrm{~cm}$ のガラス球を使って 構築した. 一様水深域での静水深 $h$ は $28 \mathrm{~cm}$ である. 入 射波を規則波とし，周期を 3 種類 $(T=1.0,1.4,1.8$ 秒 $)$, 入射波高 $H$ を 4 種類 $(3.0,5.0,7.0,10.0 \mathrm{~cm})$ 変化させ, 各々の条件に対して, 水位変動 $\eta$, 水平·鉛直方向の流速 および被覆材の作用波力 $\left(F_{x}, F_{z}\right)$ を同時に計測した。計 
測地点については，入射波の周期に応じて法面上で 4 5 箇所，天端上で $7 \sim 9$ 箇所変化させた.

\section{4. 抵抗係数の評価}

\section{1 被覆材の作用波力の算定式}

透水構造物内の流れの運動方程式に含まれる抵抗項 は, 付加質量力, 線形抵抗項と非線形抵抗項から構成さ れる.これらは流れに対しては抵抗として作用するが, 被覆材に対しては波力として作用する。一方，被覆材の 作用波力の算定式として，Morison 式の有効性が報告さ れているが, Morison 式は慣性力項と非線形な抵抗項に より作用波力を評価した式となっている，抗力項として は，その大きさが小さいために Morison 式には考慮され ていないが，線形抵抗も作用していると考えられ，特に 外部領域に比べて流れが遅くなる透水構造物内では線形 抵抗項も重要な寄与をすると考えられる.この線形抵抗 項を Morison 式に付加すると, 形式的には運動方程式中 の抵抗項と同形となる。そこで，本研究では，以下に示 す式（5）を被覆材の作用波力の表示式として採用する こととした.

$$
\begin{aligned}
F_{x}= & \frac{1}{8} C_{M X} \rho \pi D^{3} \dot{u}_{r}+\frac{1}{8} C_{D X 1} \rho \pi D^{2} u_{r} \sqrt{u_{r}^{2}+w_{r}^{2}} \\
& +3 C_{D X 2} \rho \nu \pi D u_{r} \quad \cdots \cdots \cdots \cdots \cdots \cdots \cdots \cdots \cdots \cdots \cdots \cdots \cdots \cdots \cdots \cdots \cdots
\end{aligned}
$$

ここに, $C_{M X}$ : 慣性力係数, $C_{D X 1}$ : 非線形抗力係数, $C_{D X 2}$ : 線形抵抗係数, である. なお, 式中の添字 $r$ は実流 速を表す。なお，実流速と流量流速との間に次式が成り 立つ.

$$
u_{r}=u / m, \quad w_{r}=w / m
$$

\section{2 透水層の抵抗}

透水構造物を均質な多孔質体で近似し，その要素に作 用する $x$ 方向の波力を式（5）を使って表示すると次式 を得る。

$$
\begin{aligned}
F_{x}= & \rho V C_{M X} \dot{u}_{r}+\frac{1}{2} C_{D X 1} \rho A_{x} u_{r} \sqrt{u_{r}^{2}+w_{r}^{2}} \\
& +3 C_{D X 2} \rho \nu \frac{S}{D} u_{r} \quad \ldots \ldots \ldots \ldots \ldots \ldots \ldots \ldots \ldots \ldots \ldots \ldots \ldots \ldots \ldots
\end{aligned}
$$

ここで, $A_{x}$ : 多孔質中の固体部分の $x$ 方向の投影面積, $V:$ 多孔質中の固体の体積, $S$ : 間吵の表面積, である. いま，単位奥行を持ち， $x$ と $z$ 方向にそれぞれ $\Delta x, \Delta z$ の 長さを持つ微小要素を考えると, 式 ( 7 )の $A_{x}$ と $V$ は以 下のように表示できる.

$$
\begin{aligned}
& A_{x}=(1-m) \Delta z \cdots \\
& V=(1-m) \Delta x \Delta z
\end{aligned}
$$

榊山ら（1990，1991）は，体積空隙率と表面空吵率を独 立に扱っているが, 本研究では上式のように一定とした。

式（8）と式（9）を式（7）に代入し，さらに式（6） を使って流量流速で表示すると微小要素に作用する $x$ 方
向の波力 $f_{x}$ は次式で与えられることになる.

$$
\begin{aligned}
f_{x}= & C_{M X} \rho \frac{(1-m)}{m} \dot{u} \Delta x \Delta z \\
& +\frac{1}{2} C_{D X 1} \rho \frac{(1-m)}{m^{2}} u \sqrt{u^{2}+w^{2}} \Delta z \\
& +3 C_{D X 2} \rho \nu \frac{S}{D} u \ldots \ldots \ldots \ldots \ldots \ldots \ldots \ldots \ldots \ldots \ldots
\end{aligned}
$$

上式の波力が流れに対しては抵抗として作用することに なるため, 多孔質体内の単位体積重量当たりの流体に作 用する抵抗 $R_{x}$ は次式で与えられることになる.ただし， 慣性力のうち, 入射波が本来有している圧力勾配に起因 する成分は，構造物の有無にかかわらず作用するため， 構造物の存在によって生じる付加質量の成分のみを考慮 すればよい。

$$
\begin{aligned}
R_{x}= & \frac{f_{x}}{\rho g m \Delta x \Delta z} \\
= & \frac{1-m}{g m^{2}} C_{A X} \dot{u}+\frac{1-m}{2 m^{3} g \Delta x} C_{D X 1} u \sqrt{u^{2}+w^{2}} \\
& +\frac{3 \nu}{g m d D} C_{D X 2} u
\end{aligned}
$$

ただし， $d=m V / S, C_{A X}$ ：付加質量係数，である.

式（11）で与えられる抵抗が作用する時の $x$ 方向の運 動方程式は次式となる。

$$
\begin{aligned}
& \frac{1}{m g}\left(1+\frac{1-m}{m} C_{A X}\right) \frac{\partial u}{\partial t}+\frac{1}{m^{2} g}\left(u \frac{\partial u}{\partial x}+w \frac{\partial u}{\partial z}\right) \\
& +\frac{1}{\rho g} \frac{\partial P}{\partial x}+\frac{3 \nu}{g m d D} C_{D X 2} u \\
& +\frac{1-m}{2 m^{3} g \Delta x} C_{D X 1} u \sqrt{u^{2}+w^{2}}=0
\end{aligned}
$$

式（2）と式（12）を比較すると，第 1 項から第 3 項ま では一致する。しかし，第 4 項と第 5 項の線形抵抗項と 非線形抵抗項の係数は異なる. 本研究では, 被覆材の作 用波力の実験結果から, 式 (12) 中の係数 $C_{A X}, C_{D X 1}, C_{D X 2}$ を決定し，その值を解析に使用することとした。また， 第 5 項に含まれる $\Delta x$ につては, 本研究では潜堤の構 成要素であるガラス球 1 個が含まれる大きさを最小要素 と考え，直径 $D$ を使用することとした，なお，ここでは 水平方向の波力算定式と運動方程式を示したが，鉛直方 向に対する式も同様に導くことが可能である.

\section{5. 抵抗係数の評価}

\section{1 波力係数の特性}

実験で得られた波力の時間変化と式（5）の波力算定 式による計算波力が最も良くあうように最小自乗法によ り波力係数を決定した. $\mathrm{KC}$ 数 $\left(=u_{m} T / D\right)$ の変化にとも なうこれらの係数の変動特性を図一 1 3 に示す. なお， 式（5）による計算波力と実験值の相関係数も同時に計 


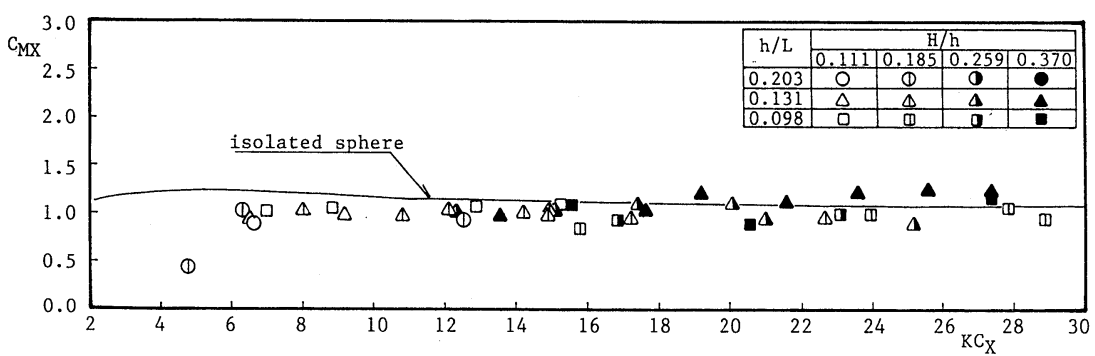

図一1 $C_{M X}$ と $\mathrm{KC}$ 数の関係

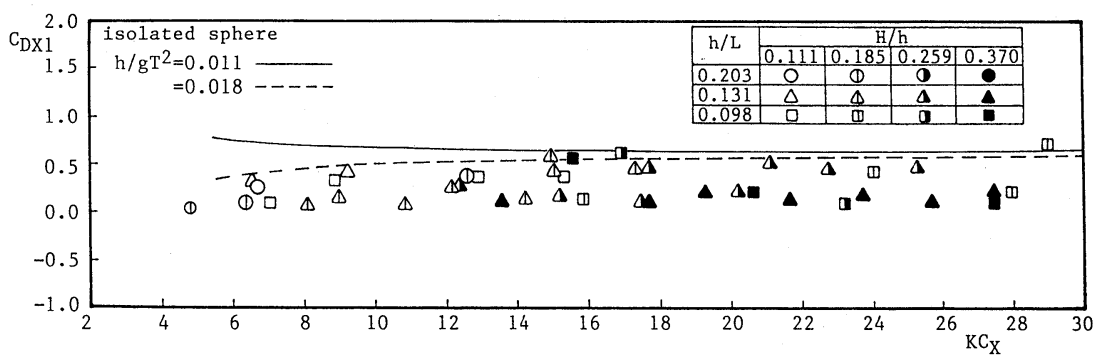

图一2 $C_{D X 1}$ と $\mathrm{KC}$ 数の関係

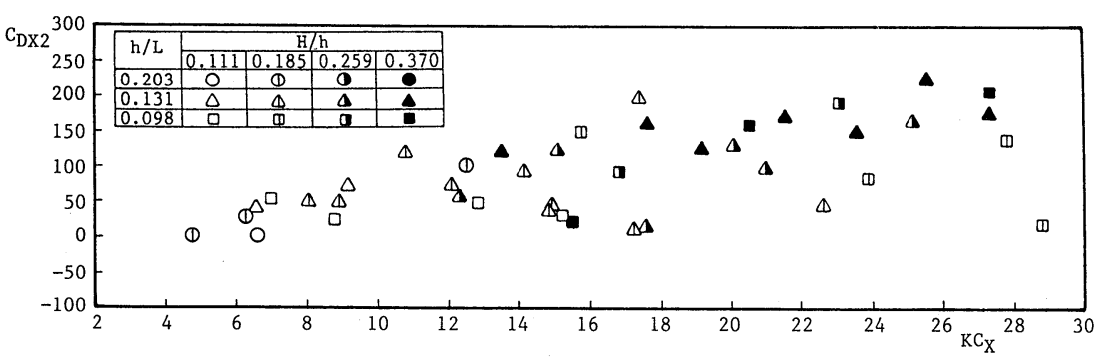

図-3 $C_{D X 2}$ と $\mathrm{KC}$ 数の関係

算し，相関の悪いものは除外してある.

図-1 に示す慣性力係数 $C_{M X}$ は, 従来の Morison 式に より抗力・慣性力の 2 つの成分に分離された場合の值と ほとんど変化はなく, 曲線で示した単一球体の平均値と の対応も良好である.

非線形抗力係数 $C_{D X 1}$ は, 図-2 に示すように, 従来の Morison 式の $C_{D X}$ に相当する係数であるため, 一様水深 域に設置された単一球体の $C_{D X}$ の平均值も図中に曲線 で示した. $C_{D X 1}$ は全体に単一球体の $C_{D X}$ の平均値よりも 小さくなるが, これは本研究では抗力項を線形・非線形 の 2 つの項に分けたためである. また, 単一球体の場合, $C_{D X}$ は抗力の卓越する $\mathrm{KC}$ 数が約 10 以上ではほぼ一定 值に収束する傾向があるものの，慣性力の卓越する $\mathrm{KC}$ 数が約 10 以下の範囲では分布の範囲が広くなることが 報告されているが（岩田・水谷, 1989), 本研究では流速
に比例する抗力を分離し ているため，非線形抗力 係数 $C_{D X 1}$ にはその影響 は認められず，抗力係数 の特性がより明確になっ たといえる。

一方，図一 3 に示す線 形抗力係数 $C_{D X 2}$ は, $\mathrm{KC}$ 数が 10〜15 以上の範囲 でばらつきが大きくな る、これは，この範囲で は非線形抗力が卓越する ため，相対的に係数に誤 差が生じやすいためであ ると考えられる。また， 流速に比例する粘性抵抗 力は位相差を伴うと考え られるが，ここではその 効果が考慮されていない ことも一原因として挙げ られる.一方, $\mathrm{KC}$ 数が 10 以下では, 比較的ばらつ きは小さくなりほぼ一 定值とみなすことが可能 である。

\section{2 抵抗係数の評価}

式（12）中の係数は, $C_{A X}, C_{D X 1}$ と $C_{D X 2}$ が決定 できれば全て求まること になる.このうち, 付加 質量係数 $C_{A X}$ は慣性力 係数から圧力係数分の 1.0 を引けばよいが, 慣性力係数 $C_{M X}$ は図一 1 に示した ように，ほぼ一定値に収束しているため，その平均值を 使用することが可能である，また，非線形抵抗係数に含 まれる $C_{D X 1}$ も図一2に示すようにほぼ一定值とみなせ るため, 平均值で評価できる。

一方, 線形抵抗係数中の $C_{D X 2}$ は, 他の係数に比べてば らつきが大きい. しかし, この項が重要となるのは, 比 較的 $\mathrm{KC}$ 数の小さい範囲であることが予想され，実際， $\mathrm{KC}$ 数が 10 以上では非線形な抗力に比べて線形の抗力 の寄与は小さいことを確認している(前田，1996). そこ で, 本研究では, 多少のばらつきはあるが, KC 数が 10 以 下の範囲の平均値で $C_{D X 2}$ を評価することとした。

以上の考察に基づき, 最終的にそれぞれ $C_{M X}=$ $0.96\left(C_{A X}=-0.04\right), C_{D X 1}=0.45, C_{D X 2}=25.0$ として解析 に使用した。また，図示していないが，鉛直方向の計算 
波力は全般的に実験值の一致度が低く, 波力係数に水平 方向波力の場合のような明確な特性を見出すことができ なかったため, 鉛直方向の抵抗係数も水平方向波力に対

して評価した値をそのまま使用した。

\section{6. 数値解析結果}

\section{1 水面変動}

図-4 は, 潜堤上の波変形の計算結果を実験値と比較 した結果を例示したものである。なお，比較のために水 谷ら（1995）が行ったように McCorquodale・Hannoura の係数をそのまま使用した結果も示してある. 同図に示 すように, $x / L=0.3$ では本研究の計算結果は若干の差異

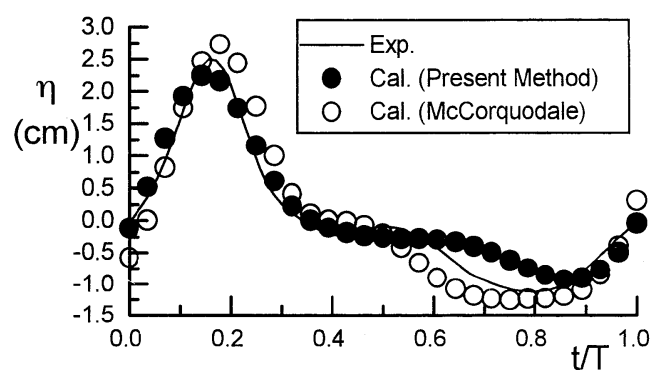

(a) $x / L=0.3$

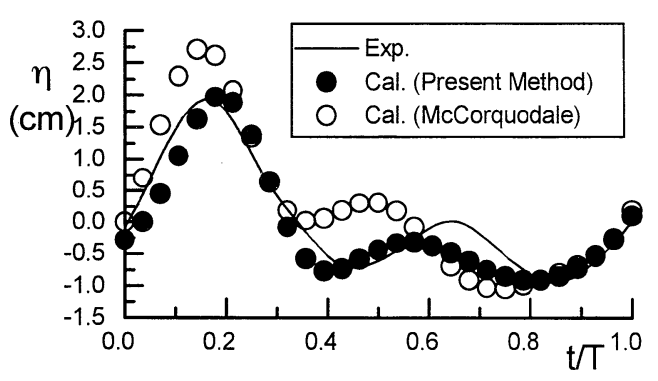

(b) $x / L=0.5$

図一4 潜堤上の水面変動の比較例 $\left(h / g T^{2}=0.146, H / h=0.107\right)$

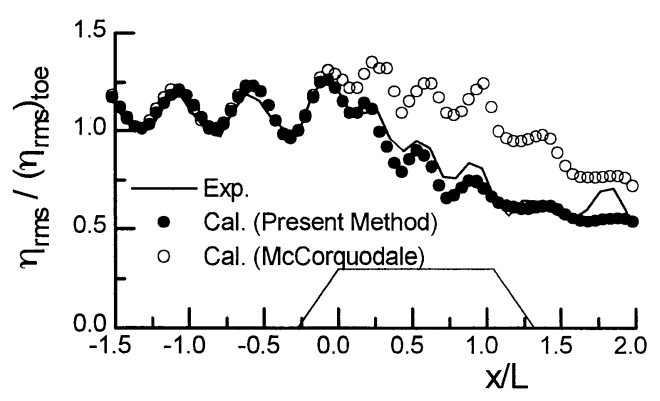

図一5 $\eta_{\mathrm{rms}}$ の変動特性の比較例 $\left(h / g T^{2}=0.146, H / h=0.107\right)$
はあるものの，実験值に近い，また，従来の係数を使っ た場合も実験值との対応は悪くない. しかし， $x / L=0.5$ になると, 本計算結果と実験值との間には良好な一致が 認められるのに対して，従来の係数を使用した計算結果 は波峰高を過大評価している。図示していないが，この 傾向はさらに $x / L$ が大きくなるとより顕著になること が判明した。この原因は抵抗係数が妥当に評価されてい ないために, 潜堤内のエネルギー損失を過小評価し, 波 が潜堤上を通過してもあまり減衰しないことによると考 えられる。

図一 5 は, 潜堤前後を含む水位変動の $\mathrm{rms}$ 值 $\eta_{\mathrm{rms}}$ の空 間分布を示した結果である，潜堤前面の水域では，潜堤 からの反射波と入射波が部分重複波動場を形成するた め, $\eta_{\mathrm{rms}}$ は $x / L$ が 0.5 の空間的な周期で変動する.いずれ の計算值も実験值にほとんど一致している.したがって, 両計算結果とも構造物からの波の反射を妥当に再現して いるといえる.

一方，潜堤上では，本計算結果と実験結果のいずれか らも, $\eta_{\mathrm{rms}}$ は波の分裂の影響と思われる変動を伴いなが ら減衰していくのが確認でき，また，定量的にも両者は ほとんど一致している。さらに両者は潜堤背後でもほぼ 同じ値になっており, 本計算結果は実験結果の $\eta_{\mathrm{rms}}$ の挙 動を精度良く再現しているといえる. しかし, 従来の係 数を使った計算結果は, 潜堤上の $\eta_{\mathrm{rms}}$ の減衰を過小評価 しており，潜堤背後では実験值をかなり過大に評価して いる. 水谷ら (1995) は, McCorquodale・Hannouraの 係数をそのまま使用しても潜堤上のエネルギー減衰を妥 当に評価できることを報告しており，図-5 の結果と異 なるが，これは以下の理由によると考えられる．水谷ら は, 矩形の潜堤を対象に計算を行っているため, 構造物 からの反射波が本研究で対象としている台形の潜堤に比 べて大きい. そのため, 潜堤上を通過し, 背後へ伝播す るエネルギーは小さくなり, 潜堤背後では実験值とほぼ 同じになったと考えられる.そしてその間で $\eta_{\mathrm{rms}}$ が減衰 する挙動に近くなったと考えられる.

\section{2 流速}

潜堤内の流速べクトルの様子を図一6に示す．波峰の 位置では岸向きの流れが，また，谷の位置では沖向きの

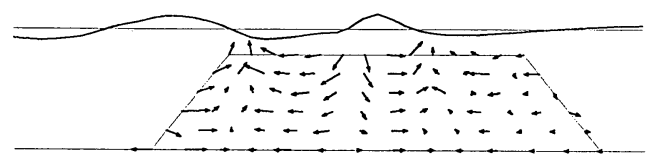

- $1 \mathrm{CM} / \mathrm{S}$

図一6 潜堤内の流速ベクトルの計算結果 $\left(h / g T^{2}=0.286, H / h=0.107, t / T=5.0\right)$ 


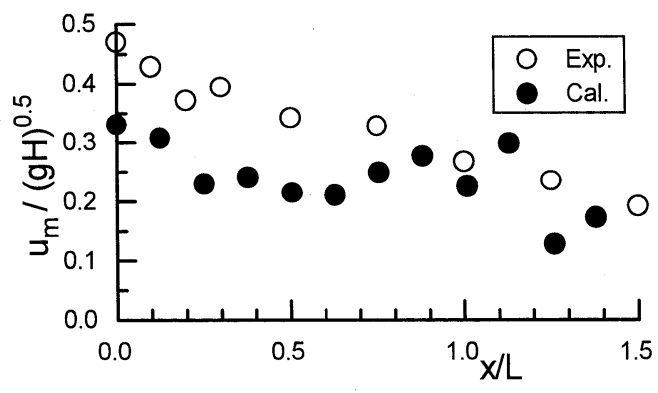

（a）水平方向流速

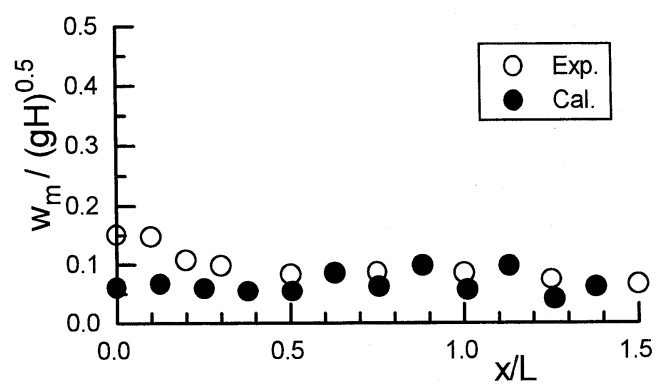

(b) 鉛直方向流速

図一7 潜堤天端上の最大流速の比較例 $\left(h / g T^{2}=0.286, H / h=0.107\right)$

流れが計算されている．また，ゼロアップクロス点では 上向き，ゼロダウンクロス点では下向きの流れが確認で き，さらに流速の大きさも底面に近づくにしたがい減少 するなど，妥当な流れが再現されていることがわかる.

図一7に，周期 1.0 秒，波高 $3.0 \mathrm{~cm}$ の場合の天端上の 最大流速の分布を示す. 同図 (a) は水平方向の無次元最 大流速 $u_{m} / \sqrt{g H}$ を示しているが, 実験值は流速計を潜堤 上に突出させて計測した実流速であるため，計算值を間 隙率 $m$ で割り実流速に換算した值で実験值との比較を 行っている. 図より, 実験值については, $x / L=0.0$ であ る沖側法肩での值を最大值とし，ほぼ一様の勾配で減少 している.計算值は，全体的に $x / L$ の増加にともない減 少する傾向は実験值と同様であるものの，その勾配は相 対的に緩く，また值も小さい。これは実際に計測した流 速は潜堤の外部であるため，実際には表面での流速より も大きくなっているためである.

図一7 (b) は, 鉛直方向の無次元最大流速 $w_{m} / \sqrt{g H}$ の $x / L$ にともなう変動特性を示したものである.ただし, 鉛 直方向流速については, 流速計センサーは有限な值を 持っており，被覆材と空隙を含む潜堤表面の平均的な流 速を計測していることになるので，流量流速のまま比較
を行っている．図より，潜堤沖側の法肩付近で実験值と 計算值の間に大きな差が認められる。これは，沖側法肩 付近では斜面に添った流れの鉛直方向成分も計測してい るため,実験值が大きくなったことによると考えられる. しかし，それ以外では，実験值との間に多少の差異はあ るものの，実験条件との差異を考慮すれば計算值は妥当 な值であると考えられる。

\section{7. 結言}

本研究では，まず，被覆材の作用波力を計測し，その 結果を流れが受ける抵抗項と関連づけることにより，波 動場における透水構造物内の流れの抵抗係数の評価を 行った。そして，その結果を波・幅広潜堤の非線形相互 作用問題の数值解析手法に適用することにより, 水位変 動や堤体内の流れの予測精度が向上することを確認し た. 本研究で評価した抵抗係数は, ガラス球で構築した 構造物に対するものであるが，今後，自然石で構築した 場合の係数についても検討を加えていく所存である.

最後になるが，本研究を遂行する上で多くの助言を 賜った名古屋大学の岩田好一朗教授に感謝の意を表す る.

\section{参 考 文 献}

岩田好一朗・水谷法美（1989）：没水球体攺作用する波力の特性 に関する研究, 土木学会論文集, 第 405 号/II-11, pp. 215-224. 大山 巧 (1991)：数值波動水槽の開発と非線形波動解析への応 用, 東京工業大学博士学位論文, $132 \mathrm{p}$.

榊山 勉(1992)：潜堤による非線形波の分裂に関する数值解析， 海岸工学論文集, 第 39 巻, pp. 626-630.

楖山 勉・阿部宣行・鹿島遼一 (1990)：ポーラスモデルによる 透過性構造物周辺の非線形波動解析, 海岸工学論文集, 第 37 巻, pp. 554-558.

榊山 勉・鹿島遼一・阿部宣行 (1991)：傾斜堤周辺の波動場解 析へのポーラスモデルの適用性, 海岸工学論文集, 第 38 巻, pp. $546-550$.

前田健一郎 (1996)：潜水透水性構造物による波浪変形の解析法 に関する研究，名古屋大学工学研究科修士論文, $24 \mathrm{p}$.

水谷法美・岩田好一朗・Teofilo M. Rufin Jr.・戸塚奈津子・倉田 克彦 (1994)：幅広潜堤の被覆捨石の安定重量の算定法に関 する実験的研究, 海岸工学論文集, 第 41 巻, pp. 781-785.

水谷法美・後藤敏明・W. G. McDougal（1995）：潜水透水性構造 物による波変形と内部流速場のハイブリッド数値解析, 海岸 工学論文集, 第 42 巻, pp. 776-780.

Rufin Jr., T. M. ・ 戸塚奈津子・水谷法美・岩田好一朗・倉田克彦 (1993)：潜堤の被覆捨石に作用する波力に及ぼす捨石の形 状効果について, 海岸工学論文集, 第 40 巻, pp. 801-805.

McCorquodale J. A. and Hannoura A. A (1978): Hydraulic Conductivity of Rockfill, J. Hydraulic Research, No. 2, pp. 123-137. 